\title{
DIREITOS SOCIAIS, FEDERALISMO E POLÍTICAS DE MORADIA NO BRASIL
}

RogérIo Luiz NeRY da SiLVA

Pesquisa Pós-doutoral em andamento na Université de Paris X em Direitos Fundamentais e Ciência Política; Pós-Doutorado em Constitutional Law (New York Fordham University School of Law - EUA), Doutor em Direito Público (UNESA), Professor-doutor da disciplina de Políticas Públicas de Efetivação dos Direitos Sociais, no Programa de Pesquisa, Pós-graduação e Extensão da Universidade do Oeste de Santa Catarina - Mestrado em Direito (UNOESC); Pesquisador do Grupo de Pesquisa em Direitos Fundamentais Sociais da UNOESC; Professor da Escola da Magistratura do Estado do Rio de Janeiro (EMERJ) e da Escola do Ministério Público do Estado do Rio de Janeiro (FEMPERJ).

ROBISON TRAMONTINA

Doutor em Filosofia (UFSC), Professor-doutor da disciplina de Filosofia do Direito, no Programa de Pesquisa, Pós-graduação e Extensão da Universidade do Oeste de Santa Catarina - Mestrado em Direito (UNOESC); Pesquisador do Grupo de Pesquisa em Direitos Fundamentais Sociais da UNOESC.

\section{Resumo}

Este estudo faz a aproximação entre os temas dos direitos sociais, pelo lado do direito e das políticas públicas, pelo da ciência da administração, contextualizados no espaço de atuação do federalismo. Justifica-se a escolha, em razáo de os primeiros se verem, via de regra, assolados por obstáculos de ordem política, jurídica, financeira, orçamentária, ideológica e, mesmo, semântico-interpretativa. A efetividade desses direitos reclama a implantaçáo de políticas de Estado e de governo que representem compromisso permanente quanto à oferta e à garantia de acesso a determinadas prestaçóes e a determinados serviços públicos, caracterizadores do atendimento da demanda social por vida digna, notadamente, por parte da populaçáo mais carente, que envolve expectativas desde as necessidades de subsistência mais elementares - como alimentação e moradia -, às de maior complexidade relacionadas com o desenvolvimento como pessoa e como cidadáo, destinatário de uma participação crítica na vida em sociedade, tais como a educação e a cultura. Utiliza-se o método indutivo, com o propósito de relacionar os direitos sociais ao federalismo, o que se justifica pela exigência de melhor identificar os atores públicos responsáveis pelas políticas públicas, quer econômicas, quer sociais, e quais os seus deveres 
jurídicos exigíveis para a concretização de resultados. Realiza-se o recorte temático sobre o direito social à moradia, com o objetivo trazer o conhecimento das principais políticas de habitação adotadas no Brasil a partir do século XX a fim de avaliar a sua eficácia.

\section{Palavras-chave}

Direitos fundamentais sociais; Políticas públicas; Federalismo; Direito à moradia.

\section{Résumé}

Cet'étude établie une relation plus étroite entre le thème des droits sociaux, sur le côté du droit, et de politique publique, à cote de l'science de la gestion, tout contextualisées dans l'espace de la performance du fédéralisme. C'est facilement justifié comme une choix, en raison de l'existence, comme règle générale, des obstacles politiques, juridiques, financières, budgétaires, idéologiques et, encore, de la sémantique interprétative. L'efficacité de ces droits appelle à la mise en œuvre des politiques de l'Etat et du gouvernement qui représentent l'engagement continu de l'offre et de garantir l'accès à certains avantages et certains services publics, la caractérisation de la réunion de la demande sociale pour vivre dans la dignité, notamment par le population pauvre, ce qui implique des attentes de besoins de subsistance les plus élémentaires - comme la nourriture et le logement - à plus complexe liée au développement en tant que personne et en tant que citoyen, destinataire d'une participation critique dans la société, comme l'éducation et culture. Le travail utilise la méthode inductive, afin de relier les droits sociaux au fédéralisme, ce que peut etre justifié comme la meilleure condition pour identifier les acteurs publics en charge des politiques publiques, qu'elles soient économiques ou sociaux, et qui leurs obligations légales requises pour l'obtention de résultats. Le thème de la droite sociale à des logements, a été choisi comme cuore afin d'apporter la connaissance des principales politiques de logement adoptées au Brésil à partir du XXe siècle afin d'évaluer leur efficacité.

\section{Mots-clés}

Droits sociaux fondamentaux; Politiques publiques; Fédéralisme; Droit de logement.

\section{Introdução}

Os direitos sociais reclamam efetividade mediante a adoção de políticas públicas eficazes, cujo processo de elaboração, adoção, monitoramente e avaliação, por si só, já se mostra bastante difícil, mesmo nas sociedades e Estados de mais simples organizaçáo. Este aspecto pode assumir contornos de complexidade ainda maior quando se trata de estados de 
organização federativa, cujo arranjo governamental, de competências e atribuiçôes constitucionais, pode assumir forma de mosaico caleidoscópico.

No federalismo, por vezes, as competências se postam absolutamente separadas, em paralelo; noutras, comuns ou concorrentes, interpenetradas e, em certos temas, registram um absoluto vazio, sem que nenhum ente federativo tenha recebido a incumbência clara de possuir missão constitucional àquele respeito. Além disso, registra-se maior ou menor grau de hierarquização entre as esferas políticas, embora se clame que entre as mesmas inexiste tal escalonamento.

Portanto, não bastasse a complexidade de desenvolver soluçóes políticas para os problemas da sociedade - quer governamentais, quer não; quando isso se situa na órbita federativa, a dificuldade é múltipla daquela. Ademais, é certo que políticas pontuais devem constituir exceção, complementares às grandes políticas de Estado, ao contrário do que frequentemente se verifica, políticas empiricamente adotadas, de forma e oportunidades isoladas, sem uma contextualização mais ampla, sem inserçáo em um planejamento estratégico de estado, mas impregnadas de improvisação.

Políticas públicas adequadas - quer econômicas, quer sociais -, demandam, em primeiro lugar, a identificação de seus pretensos responsáveis, os quais operarão como os verdadeiros atores sociais, seja pela protagonismo em termos de adoção de medidas materiais, de caráter concreto ou legislativas, de índole abstrata.

\section{Políticas Públicas e Direitos Sociais - Uma Estreita Correlação}

Embora se verifiquem variadas propostas teóricas para o esquema procedimental de elaboração de políticas públicas, sumariamente pode-se adotar como linhas-mestras as seguintes fases, seja mediante debate político, seja pelo método de planejamento tecnocrático: 1) o levantamento dos problemas é o ponto inicial, responsável por promover uma espécie de "brainstorm" voltado a aventar hipóteses para a formaçáo da agenda política e posterior adoção da ação política correspondente.

Ponto central será sempre a definição de atribuiçóes e responsabilidades, de modo a identificar a quem cabe elaborar ou implantar uma dada política. Cuida-se da definição e cumprimento da competência ou atribuição constitucional para tal, que pode ser, segundo o modelo brasileiro, legislativa ou administrativa. O encarregado de implantar poderá também, embora não seja a melhor opção, ter a função de controlar sua aplicação e aferir seus resultados. Seja em um estado unitário, seja em um estado plural (confederado, federado ou de via supranacional) não é nada simples a tarefa de compreender a complexa rede de relacionamentos entre os atores concorrentes em termos dessas atribuiçóes, muito particularmente se considerado o caso do modelo federativo, que demanda uma interação 
dinâmica entre os diversos atores constitucionais, seja para implantar, seja para controlar as políticas públicas ou o atendimento de seus objetivos.

Qualquer política reclama para seu estabelecimento a condução de amplo diálogo, intra, extra e interinstitucional, entre os diversos atores sociais e entre estes e o poder público, portanto, dentre as mais variadas esferas deliberativas, que se comportam complementarmente na construção das políticas públicas, aí incluída a própria sociedade civil, como player cada vez mais atuante, o que nem sempre se mostra de fácil adequação e execução. O desenho federal, sobretudo, hospeda algumas tensóes gerais no contexto político-econômico modelo brasileiro, principalmente em temas de políticas sociais, tanto as de saúde, como as educacionais ou habitacionais, todas protagonizam sérias pressóes.

Com a opçáo pelo modelo inovador de federalismo cooperativo pela Constituiçáo de 1988, tem-se por necessária a complementação mútua entre as múltiplas competências constitucionais atribuídas a cada ente federado, ou seja, embora possa haver uma distribuição de competências relativamente bem delineada, nada impede, ao contrário, espera-se que os entes federados e suas entidades derivadas - como atores sociais públicos - venham a se complementar entre si.

A adoção pelo Brasil da norma ISO 26000 sobre Responsabilidade Social fez recair sobre as organizaçóes, tanto públicas como privadas, o papel de atores sociais e o decorrente dever de agir com sustentabilidade e inclusão social. Portanto, não importa em que nível governamental ou de governança empresária se esteja, o compromisso social estará presente, o que permite concluir, sem embargo, que também ao arranjo federativo se impóe tal submissão, conforme bem pontuam Dias et Matos $^{1}$.

Embora o Supremo Tribunal Federal (STF) tenha firmado entendimento no sentido da não normatividade do texto do preâmbulo da Constituição, é também entendido pelo tribunal o papel e importância do preâmbulo como fonte interpretativa. Por isso, o fato de o preâmbulo assegurar o exercício dos direitos sociais e individuais, à liberdade, à segurança, ao desenvolvimento, à igualdade e à justiça como valores a serem preservados em todas as esferas da federação adota a forma de princípio interpretativo constitucional em busca do pluralismo social.

A Constituição impóe ao Estado o dever disponibilizar os meios materiais e condiçôes fáticas para o efetivo gozo das liberdades públicas e dos direitos sociais para a efetivação da garantia de liberdade perante o Estado (autonomia) e, também, da liberdade por intermédio do Estado (patrocinada pelo Estado). Isso se comprova pela escolha política

1 DIAS, Reinaldo et MATOS, Fernanda. Políticas Públicas - princípios, propósitos e processos. São Paulo: Atlas, 2012, p. 177. 
do constituinte em conferir no texto constitucional, a exclusividade de um capítulo inteiro, no contexto do título II - Dos Direitos Fundamentais, na Constituição de 1988.

Não tem cabimento a discussão sobre a fundamentalidade dos direitos sociais, só pelo fato de eles estarem ausentes do rol do artigo $5^{\mathrm{o}^{2}}$, pois que eles preenchem todos os requisitos jusfilosóficos para serem considerados direitos fundamentais. A controvérsia acerca da fundamentalidade dos direitos fundamentais sociais, em verdade, trabalha a serviço de quem deve pagar a conta das políticas sociais, portanto, da administração pública e da sociedade. A defender os direitos sociais têm-se os próprios destinatários das prestaçôes, parte engajada da sociedade civil.

A respeito da participação da sociedade civil, é necessário registrar também a existência de uma parcela de pseudoatores políticos que atuam de forma demagógica ou em busca de benefícios próprios, tais como dividendos políticos, eleitorais ou não.

A arquitetura constitucional fornece rico material ao debate acerca de uma suposta deficiência d positivação dos direitos sociais: $\mathrm{O}$ art. $5^{\circ}$, parágrafo $1^{\circ 3}$, por exemplo, menciona a aplicabilidade imediata das normas reguladoras de direitos fundamentais. Agregase a esse raciocínio o conteúdo do art. $5^{\circ}$, parágrafo $2^{0^{4}}$, que reconhece status constitucional fundamental, operando como "cláusula de abertura ou de resgate interpretativo".

São por ela reconhecidos os direitos identificados com os princípios (fundamentais), o regime (social-democrático) da Constituição Brasileira, assim como os direitos que decorram dos tratados internacionais (de direitos humanos).

Estes últimos exigem uma interpretação conjunta com o conteúdo do artigo $5^{\circ}$, parágrafo $3^{05}$ para sua efetiva equiparação ao status de norma constitucional.

Por mais reduzida que seja a densidade das normas de direitos sociais, assegurada está a sua "aplicabilidade imediata", mesmo as que têm reconhecida índole programática. Tal entendimento encontra respaldo em jurisprudência do $\mathrm{STF}^{6}$, em diversos votos do Min. Celso de Mello, hoje seu decano.

2 "Art. 50 Todos são iguais perante a lei, sem distinção de qualquer natureza, garantindo-se aos brasileiros e aos estrangeiros residentes no País a inviolabilidade do direito à vida, à liberdade, à igualdade, à segurança e à propriedade, nos termos seguintes: (...)"

3 "Art. $5^{\circ},(\ldots) \$ 1^{\circ}$ - As normas definidoras dos direitos e garantias fundamentais têm aplicaçáo imediata."

4 "Art. $5^{\circ},(.) \.$ 2^{\circ}$ - Os direitos e garantias expressos nesta Constituiçáo nấo excluem outros decorrentes do regime e dos princípios por ela adotados, ou dos tratados internacionais em que a República Federativa do Brasil seja parte."

5 "Art. $5^{\circ},(\ldots) \$ 3^{\circ}$ Os tratados e convençôes internacionais sobre direitos humanos que forem aprovados, em cada Casa do Congresso Nacional, em dois turnos, por três quintos dos votos dos respectivos membros, serão equivalentes às emendas constitucionais. (Incluído pela Emenda Constitucional no 45 , de 2004)

6 O Supremo Tribunal Federal é o órgão máximo da estrutura do Poder Judiciário no Brasil, encarregado, dentre outras atribuiçôes da guarda da Constituição pelo controle de constitucionalidade, nos modais concentrado e difuso. 
Canotilho ${ }^{7}$ considera que os direitos subjetivos públicos, sociais, econômicos e culturais são: "independentes, quanto a sua irredutível dimensão subjetiva, das imposições constitucionais e da concretização legislativa"; e, ainda, "mesmo na parte em que pressupóem prestações do Estado, são direitos originários a prestaçóes (fundados na constituição) e não direitos a prestaçóes derivados da lei".

$\mathrm{Na}$ doutrina brasileira, as normas programáticas, enquanto não regulamentadas por legislação infraconstitucional, mesmo que atingidas pela falta de "eficácia jurídica positiva", tem reconhecida a sua "eficácia jurídica negativa ou interpretativa ou de bloqueio". Ou seja, mesmo quando construídas como normas programáticas, as normas de direitos sociais tem o condão de servir de fonte interpretativa negativa, como limites a atuação do Estado em sentido oposto, ou seja, inibem comportamentos contrários aos interesses tutelados pelas referidas normas.

Sáo efeitos concretos ou concretizáveis das normas veiculadoras de direitos sociais: a um, a promoção da estrita vinculação do legislador aos parâmetros por elas preestabelecidos, como normas definidoras de direitos fundamentais prestacionais, sendo-lhe vedado agir em sentido contrário, o que comparativamente se aproxima do conteúdo axiológico e semântico do princípio da proibição do retrocesso. A dois, a "suspensão da eficácia" de leis e atos normativos editados na vigência da nova Constituição e que com elas conflitem, pelo mecanismo da necessária e vinculativa "declaraçáo da inconstitucionalidade". A três, a revogação tácita de leis ou dos atos normativos anteriores, cujo conteúdo se mostre contrário, pelo mecanismo da "não recepção". A quatro, serem as referidas normas programáticas situadas como parâmetro interpretativo ou integrativo de normas jurídicas outras ou de lacunas do ordenamento, como bem preleciona Canotilho ao pontuar com tamanha clareza que "os direitos subjetivos a prestaçóes, mesmo quando não concretizados, existem para além da lei, por virtude da Constituição, podendo, podendo ser invocados, (embora não judicialmente) contra as omissóes inconstitucionais do legislador.”

Também é prestigiada pelo direito brasileiro a possibilidade de invocação ao cumprimento - bem defendida pelo dileto professor lusitano, quando identificada a omissáo legislativa. Entretanto, por aqui, ela se opera com ainda maior desenvoltura, pois viável a arguição também em sede judicial.

O constituinte brasileiro fez-se arrojado, ao oferecer soluçóes jurídicas, para além (ou depois) das políticas - é claro, que se póem a constituir o legislador em mora constitucional legislativa e notificá-lo para que venha adimplir seu dever constitucional.

Refere-se aqui, em hipótese, à Ação Direta de Inconstitucionalidade por Omissão (ADIO) e ao Mandado de Injunção (MI): a primeira, de emprego concentrado e abstrato;

7 CANOTILHO, José Joaquim Gomes. A Constituição Dirigente e a Vinculação do Legislador - contributo para a compreensão das normas constitucionais programáticas. Coimbra: Almedina, 2001, 371. 
o último de emprego difuso e concreto, instrumentos jurídicos que deixaráo de ser, aqui, mais bem detalhados, por não se constituírem objeto central do presente trabalho.

Cabe, entretanto, registrar que, quanto à operação, há teses conflitantes: 1) tese não concretista; 2) tese concretista geral; 3) tese concretista individual, por sua vez, subdividida em: a) concretista individual direta e b) concretista individual indireta.

A principal das estratégias daqueles que se entendem contrários à eficácia fundamental dos direitos sociais é negar a fundamentalidade dos mesmos, pelo emprego alternado ou conjunto de 3 (três) argumentos topográficos, registre-se, de duvidoso embasamento teórico:

O primeiro desses argumentos se póe quanto ao posicionamento físico, no texto da Constituição Brasileira, como cláusulas pétreas, apenas dos direitos individuais, sem menção expressa aos direitos sociais (art. 60, parágrafo $4^{\circ}$, inciso IV). Tal assertiva é francamente combatível por simples análise igualmente literal da denominação do Título II, da Constituição, - "Dos Direitos Fundamentais”, que engloba a ambas as espécies: o capítulo 1 (artigo 50) - Dos direitos individuais e coletivos e o capítulo 2 (artigos $6^{\circ} \mathrm{e}$ 7o) - Dos direitos sociais.

O segundo argumento topográfico da divisão entre direitos individuais e direitos sociais se refere à classificação de Bobbio como diferentes geraçóes de direitos humanos, que, por isso justificaria distintos graus de fundamentalidade, atribuindo-se aos sociais a caracterização como "direitos de $2^{\text {a }}$ ordem". Contra esse argumento, basta recorrer ao princípio da historicidade dos direitos humanos, que reconhece a evoluçáo do reconhecimento dos direitos humanos, segundo processo gradual que acompanhou a própria luta da sociedade, primeiro, pela liberdade (Sec. XVIII); depois, pela igualdade (Sec. XX).

Portanto, a classificação decorre da evolução histórica na luta pelo reconhecimento, mas em nada se relaciona em termos de juízo axiológico comparativo entre essas duas classes de direitos.

O terceiro argumento, também topográfico, ainda como variante dessa mesma linha de sustentação, reside no fato de os direitos individuais e sociais terem sido, quando objeto de pactuação pela Organização das Naçôes Unidas, posicionados em diferentes documentos.

Sim, de fato, a ONU adotou: o Pacto dos Direitos Civis e Políticos e, separadamente, o Pacto dos Direitos Econômicos, Sociais e Culturais. O que não sustenta a justificativa de tratamento diferenciado em termos de cogência e fundamentalidade; tal sustentação tem manifesto intuito denegatório da eficácia fundamental e pode ser combatido pela simples invocação do princípio da indivisibilidade dos direitos humanos, que não admite segmentação axiológica entre os mesmos, qualquer que seja a razão taxionômica de organização dos mesmos em classes, espécies, tipos etc. 
Certo é que os direitos sociais têm assento constitucional e como tais são dotados de fundamentalidade, em diferentes graus e, segundo a relação de pertinência com cada indivíduo da sociedade, sendo compreensível que: a) as limitaçóes de recursos do Estado náo permitem entregar todos os direitos sociais a todas as pessoas componentes da população (tese de reserva do financeiramente possível); b) seria utopicamente desejável que se pudesse prestar a tutela social nos parâmetros máximos, para atender à populaçáo em geral (tese da máxima efetividade das normas constitucionais dirigentes); c) de outra sorte, se não é viável dar tudo a todos, tampouco se admite que as limitaçóes orçamentárias possam justificar negar a determinada parcela dos indivíduos, as prestaçóes mínimas necessárias à vida humanamente digna, permitindo-lhes viver abaixo do nível mínimo admissível de dignidade (tese do mínimo existencial).

Sarlet ${ }^{8}$ registra a efetiva dependência de fatores econômicos e jurídicos para o atendimento de direitos sociais prestacionais positivos, o que consubstancia verdadeira limitaçáo fática à efetivação desses direitos, que por essa mesma razão, são ditos como dotados de relatividade, ao se verem condicionados: por vezes, à disponibilidade de recursos públicos; por outras, à necessidade de interposição legislativa para a sua regulamentação.

Quando cabalmente demonstrada, por meio de fatos e balanços de custos e resultados administrativos, a teoria da reserva do financeiramente possível, pode apresentar-se como argumento de redução, mas jamais como excludente de responsabilidade quanto à obrigação administrativa no financiamento de certos direitos sociais enquadrados no que se reconhece como "mínimo existencial”.

$\mathrm{O}$ argumento segundo o qual, o Estado somente é dado por obrigado, dentro dos estritos limites que lhe sejam de razoável realização, sob a ótica material, perde espaço em razão da efetiva necessidade a ser suprida em termos de mínimo vital e de ideal de dignidade em termos de interesses jurídicos legítimos dos indivíduos, isolada ou coletivamente considerados.

Para o atendimento ao arranjo fático entre a necessidade de suprir as demandas sociais da população e de aperfeiçoar o necessário emprego de recursos sabidamente escassos, mais clara se mostra a inter-relação poder econômico versus efetividade.

De outro lado, ante a observância obrigatória do princípio republicano da eficiência, pela administração pública - direta, indireta ou descentralizada -, uma menor pujança econômica, pura e simples, não serve de "salvo conduto" ao estado ou seus representantes, face à omissão ou deficiência, no plano concreto, de seu dever prestacional dos serviços públicos, quer parciais, quer integrais. Há de se registrar uma severa recessão para se acolher certos argumentos, e ainda assim, muito restritamente.

8 SARLET, Ingo Wolfgang. A Eficácia dos Direitos Fundamentais. 10 ed. rev. ampl. atual. Porto Alegre: Livraria do Advogado, 2010, 288. 
Quanto à efetivação dos direitos fundamentais sociais, o conjunto indica a clara imprescindibilidade do debate pela busca da harmonia das relaçóes estado x população, mediante a ação horizontal e conjunta, cooperativa, de todos os entes federados, em todos os níveis, conforme o esboço federativo do considerado.

Já, quanto à forma de estado, no federalismo ou nos federalismos, cada estado em sua vida política acaba por desenhar - com fatos e escolhas - o seu próprio modelo federal, não sendo nada fácil, como já pontuado na visão iheringiana, forçar o enquadramento da realidade aos standards preexistentes.

As políticas públicas de Estado ou governamentais, no contexto do Federalismo não podem se conformar a uma dimensão estática na extensão ou no tempo; ao contrário, precisam comportar arranjos dinâmicos, aptos a se adaptarem às necessidades de cada sociedade, a cada tempo, como forma intuitiva de cumprimento do mandamento lassalista de conformação da realidade constitucional aos "fatores reais de poder".

A título de atualidade, entretanto, obriga tristemente registrar que, embora em contexto de crise econômico-financeira aguda, quando o Estado se vê obrigado a rever todas suas metas fiscais, por verdadeira e absoluta inexistência de recursos, o argumento da exigibilidade sofrerá uma mitigação fática, que em nada desqualifica a sua força axiológica ou normativa, mas, diante das impossibilidades fáticas, terrivelmente pode comprometer a efetiva entrega dos prestaçóes ou dos serviços tão necessários à vida digna.

\section{Políticas Públicas Sociais - Tensões Federativas na Tomada de Decisões sobre Políticas e na Repartição de Recursos Financeiros}

Historicamente, a forma de administração adotada, desde a proclamação de República no Brasil até a primeira quartel do século XX mostrou-se, mesmo com variaçóes e matizes, centralista e burocrática, de postura privatista, com moldes europeus de rígida hierarquização financeira.

No Brasil, vigorou a denominada política do "café com leite"9 até 1930, depois substituída pelo chamado "Estado Novo", que alterou a prevalência do poder político com centralismo público interventor e redução do espaço privado, mudança inspirada no modelo rooseveliano ${ }^{10}$, de origem norte-americana.

9 Nome dado à política vigente no Brasil, durante a chamada $1^{\text {a }}$ República, período em que se alternavam no poder as oligarquias dos estados de Sáo Paulo e de Minas Gerais, cujos poderes econômicos repousavam, respectivamente, sobre as suas ricas produçóes de café e de laticínios.

10 O New Deal adotou viés intermediário, a um só tempo permeado pelo ideário cooperativo, e por gestão inovadora, mas, com índole interventora que promoveu resultados muito favoráveis nos anos seguintes à Crise de 1929. 
$\mathrm{Na}$ Europa, a autoadministração marcou a introdução da noção de ideal gerencial, sob as ondas do New Public Management, que inovou ao implantar o "estado gerencial europeu", por lá desdobradas no pós II Guerra e que serviriam de inspiração ao desenvolvimento de um modelo alternativo, também chamado nos Estados Unidos de estado regulador, e que veio a substituir à práxis do estado liberal e à do estado-providência, ambas dali em diante superadas.

As inovaçóes gerenciais implantadas na Europa chegaram ao Brasil com certo atraso (delay), já que as práticas burocráticas centralistas e interventivas se prolongaram até o último quartel do século XX, tendo seu declínio materializado somente por sucessivas crises econômicas nos anos 1970 (alta do petróleo), 1980 (mercado financeiro internacional) e 1990 (recessão econômica) do século XX que apontaram para a necessidade de redução da estrutura operacional do Estado e dos consequentes ônus de funcionamento de suas máquinas, cuja racionalidade financeira exigia inexorável redução dos custos públicos. Surpreendentemente, o Brasil atravessou muito bem a crise econômico-financeira global de 2008, fruto dos muitos anos de reestruturação econômico-administrativo desde os anos 1970 .

A definição das agendas e a alocação de recursos a serem aplicados às políticas sociais demanda um amplo debate nacional acerca da origem dos recursos para fins não só de fiscalidade, mas, sobretudo, de planejamento estratégico, o que nem sempre ocorre.

Cresce em importância a discussão em torno da vinculação de receitas e sua consequente destinação de recursos a determinados objetivos sociais, como se verifica predominantemente com a educação e a saúde.

De igual tensão se faz a disputa entre outros objetivos por parcelas orçamentárias, assim como de cada ator político por recursos aptos ao atendimento das prestaçóes sociais. Veja-se o caso emblemático da disputa por recursos se deu com relação à chamada Lei Kandir, em matéria de exportações, que ainda hoje causa grande insatisfação nos estados da federação, especialmente porque as iniciativas protagonizadas pela União, como representante da República Federativa do Brasil nem sempre representam efetivamente os reais interesses de cada unidade da federação, ao contrário, por vezes entram em choque com os de outros entes.

Registre-se também a existência de nuance semântico entre as diferenças doutrinárias entre a lei "federal" e lei "nacional", referentes aos reais destinatários de cada lei aprovada no Congresso Nacional: a um, a esfera federal, ou seja, órgãos e interesses da União; a dois, a esfera nacional, quando se projeta em obrigatoriedade e executoriedade sobre todos em âmbito nacional.

A dinâmica federalista brasileira, inicialmente inspirada no modelo dual norte-americano, contudo, em que pese sua aparente harmonia arquitetônica, provocou grandes e variados descontentamentos, principalmente nos Estados-membros. 
Pode-se exemplificar pela insatisfação com o sistema político, em razão de alegada desproporcionalidade na repartiçáo das vagas no parlamento, vale dizer, que o sistema representativo proclamadamente "proporcional" à populaçáo dos estados, na prática, em razão de mecanismos contramajoritários, se mostra mais generoso com os componentes menos populosos do que com os de maior volume demográfico, que por isso se consideram injustificadamente prejudicados; outro ponto de tensão se verifica quanto à receita orçamentária, que arrecadada muito concentradamente pelos tributos de competência da União, demandam repartiçẫo entre os entes federativos, como se dá com o Fundo ${ }^{11}$ de Participação dos Estados (FPE) e o Fundo de Participação dos Municípios $(\mathrm{FPM})$. As reclamaçôes são de variadas ordens, desde os critérios de distribuição, até a própria operação do sistema, em termos de atendimento preferencial aos estados governados pelos mesmos partidos da base governamental, em prejuízo dos estados geridos pela oposição.

A eficácia das políticas sociais e a potencial - mas não necessariamente consequente - eficácia dos direitos sociais sofrem forte influência de iniciativas voltadas a reformular a prestaçẫo dos serviços públicos essenciais tais como saúde, educação e transporte, de modo a reformulá-los a fim de conferir-lhes mais eficiência.

A esse respeito, novas investidas que visem ao redesenho do arranjo de atribuiçôes federativas, em especial no tocante às responsabilidades das distintas esferas governamentais no atendimento dos direitos sociais, são frequentemente muito discutidas, mas de difícil consenso.

Basta que sejam examinadas as muitas reformas administrativas pelas quais trilhou a nação (EC19/98, EC41/04 e EC 47/05), assim como as tantas reformulaçôes dos sistemas de saúde e educação, mesmo a guisa de exemplo, para constatar que os temas são complexos e não existem soluçôes mágicas.

No momento presente, todos os debates em torno de recursos para os direitos sociais e do necessário financiamento de suas políticas prestacionais se inclinam para a vinculação dos royalties a serem percebidos da prospecção e exploração do petróleo na chamada

11 Principais formas de transferências constitucionais de recursos públicos, constituídas de parte dos tributos arrecadados por ente(s) federados "superiores" e que devem ser repassados, ou seja, repartidos com os inferiores, segundo previsão constitucional, decorrente de uma lógica tributária justificável pela hipótese de incidência (fato gerador) em relação a um determinado vínculo com a entidade a ser beneficiada por parcela da repartiçẫo. São também tidas por principais transferências constitucionais, além do Fundo de Participação dos Estados (FPE) e do Fundo de Participação dos Municípios (FPM), ambos com previsão pelo art. 159 da Constituição Federal, Imposto Territorial Rural (ITR), o Imposto Sobre Operações Financeiras/Ouro (IOF-Ouro), o Fundo de Manutenção e Desenvolvimento do Ensino Fundamental e de Valorização do Magistério (FUNDEF) e o Fundo de Compensação pela Exportação de Produtos Industrializados (FPEX). Fonte: Secretaria da Tesouro Nacional do Brasil. (www..tesouro.fazenda.gov. br) 
camada do "pré-sal" ${ }^{12}$, o que tem intensificado a pressão sobre o pacto federativo principalmente quanto à divisão desses recursos.

A crise se resume, em apertada síntese, à discussão sobre os critérios de repartição das receitas decorrentes da exploração de petróleo na chamada "camada do pré-sal", objeto de concessão a empresas exploradoras.

Os estados produtores, como potenciais suportadores dos riscos da atividade econômica reagem à ideia de ter de repartir os dividendos com outros estados não produtores, por entenderem que o petróleo sairá de seus "territórios".

Do lado oposto, posicionam-se os estados não produtores a alegar o princípio da solidariedade social, no sentido de que os produtores devem ser generosos em termos de justiça distributiva e dividir esses benefícios com todos os demais estados-membros da Federação.

Ocorre que a exploração e a lavra das jazidas de petróleo constituem monopólio da União $^{13}$. Discute-se se ao proprietário do solo se garante a participaçáo nos resultados dessa exploração, conforme a lei definir. Isso porque a Constituição assegura essa participação $^{14}$ na lavra dos minerais.

Então, primeira discussão é se o petróleo é um mineral ou não. Há duas teorias confrontantes: a teoria da origem estritamente minera ${ }^{15}$ e a teoria orgânica ${ }^{16}$. Além dessa disputa científica, outra se consubstancia sobre qual o conteúdo da norma jurídica legislativa a ser veiculada pela mencionada lei.

12 Refere-se à inovadora forma de exploração de petróleo existente em camada ainda mais profunda do que a tradicionalmente explorada e que fica abaixo da crosta terrestre, formada por sal em forma de rocha petrificadas muito profundas, depositados sob lâminas menos densas e localizado no fundo dos oceanos. (Fonte:www.brasilescola.com/química/combustiveis)

13 "Art. 177. Constituem monopólio da Uniấo: I - a pesquisa e a lavra das jazidas de petróleo e gás natural e outros hidrocarbonetos fluidos;"

14 Art. 176. As jazidas, em lavra ou năo, e demais recursos minerais e os potenciais de energia hidráulica constituem propriedade distinta da do solo, para efeito de exploraçáo ou aproveitamento, e pertencem à União, garantida ao concessionário a propriedade do produto da lavra. $\$ 1^{\circ} \mathrm{A}$ pesquisa e a lavra de recursos minerais e o aproveitamento dos potenciais a que se refere o "caput" deste artigo somente poderão ser efetuados mediante autorizaçáo ou concessão da Uniáo, no interesse nacional, por brasileiros ou empresa constituída sob as leis brasileiras e que tenha sua sede e administração no País, na forma da lei, que estabelecerá as condiçóes específicas quando essas atividades se desenvolverem em faixa de fronteira ou terras indígenas. (Redação dada pela Emenda Constitucional no 6, de 1995)\$2 $2^{\circ}$ É assegurada participação ao proprietário do solo nos resultados da lavra, na forma e no valor que dispuser a lei.

15 A teoria estritamente mineral afirma que o petróleo se formou a partir de carburetos (de alumínio, cálcio), que submetidos à hidrólise, deram origem à hidrocarbonetos (metanos, alcenos,etc). Estes sob pressão e por aquecimento, teriam se polimerizado e condensado, originando o petróleo. (Fonte:http:// www.guiafloripa.com.br/sites/energia/trivia/petroleo.php)

16 A teoria orgânica alega que a presença de compostos nitrogenados, clorofilados e hormônios no petróleo pressuporia a participação animal e vegetal na sua formação. (Fonte:http://www.guiafloripa.com.br/ sites/energia/trivia/petroleo.php) 
Trata-se de disputa política controvertida, a primeira vista sobre este tema de assento constitucional, partindo-se da ótica de propriedade da área de exploração, parece claro não se tratar de repasse dos dividendos pelos estados produtores aos estados que náo conjugam da produção e, por lógico, dos riscos inerentes à mesma.

De outra sorte, o ideal distributivo aristotélico nunca pode ser a priori descartado, pois diante do vínculo de relacionamento nacional não devem as unidades federativas fechar as portas a nenhum tipo de negociação harmonizadora, especialmente diante do dever de considerar o princípio da cooperação entre os entes da Federação.

Uma pauta de discussóes bastante sugerida sobre o tema é: a quem cabe definir se a exportação do petróleo, por exemplo, é prioritária em relação a eventual exploração por nacionais ou estrangeiros, ou ainda se a exploração com exclusividade por empresas nacionais deve ser prioritária.

Em decisóes centralizadas pela União, sem que se tenha oportunizado um amplo debate nacional com a participação dos entes federados, provoca-se intenso desconforto e confronto entre os estados e municípios, principalmente os que produzem o petróleo e suportam solitários os ônus da produção, notadamente os riscos ambientais e o incômodo da pesada logística que a atividade impóe.

Nesse particular, por exemplo, o tema da licitação para a concessão da exploração dos duzentos e oitenta e nove blocos de jazidas petrolíferas da denominada "camada do pré-sal" foi que mais despertou tensão, internamente, pois, nem ao certo se teve informação exata acerca do valor de mercado dos mesmos.

Ademais, a discussão dos royalties a serem pagos em decorrência da exploração também preocupa muito, posto que seu valor percentual não ultrapassa a casa dos 15\% (quinze por cento) da receita total - o que se afigura muito baixo.

O debate federativo tem uma potencialidade represada tão forte que constituiu tema dominante dos debates de tramitaçáo da lei no. 12.351/2010, reguladora da matéria, ao ponto de a concessão de compensaçóes às indústrias petroleiras estrangeiras, supostamente em detrimento dos interesses internos, ter passado de forma muito discreta, quase despercebida da opinião pública.

Diante da intensa e tensa guerra interna estabelecida pelas disputas entre os estadosmembros da federaçáo pela repartição dos minguados 15\%, quando o debate central poderia e mesmo deveria ter-se instaurado quanto à concessão ou náo dos referidos campos de exploração, o qual deveria ter sido conduzido em nível nacional e permeado de maior transparência possível, especialmente, por se tratar de riqueza natural esgotável, tutelada pela via da preservação ambiental e constituir forma de exploração inédita, cujos riscos ambientais são meras expectativas, sem estudos conclusivos. 
Em vez de, internamente, digladiar pela divisão dos ínfimos retornos em termos de royalties, poderiam os estados-membros, por intermédio do contraponto de equilíbrio que sempre pode representar o Senado da República, ter-se contraposto à iniciativa da Uniáo de promover as rodadas de negociação dos lotes e áreas de exploração, sem que antes fosse consultada a população local envolvida e mesmo a nação - como soberana proprietária dessas riquezas - sobre a conveniência ou não de explorar ela própria os referidos campos, ainda que de forma mais distribuída no tempo, menos agressiva ao meio ambiente, e, por seguro, mais durável e quiçá também mais rentável aos brasileiros.

\section{Direito Social à Moradia na Ordem Internacional, Constitucional e Latino -Americana}

Elaborado pelo Conselho de Direitos Econômicos da Organização das Naçóes Unidas, o Pacto Internacional dos Direitos Econômicos, Sociais e Culturais, em 1966 (artigo $\left.11, \$ 1^{\circ}\right)^{17}$, só foi ratificado pelo Brasil em 1992; a inclusão da tutela do direito à moradia só alçou assento constitucional com a Emenda no 26 à Constituição brasileira, promulgada ano de 2000; conforme registra Milagres ${ }^{18}$, outros textos internacionais dos quais o Brasil é signatário dão atenção ao direito à moradia direta ou indiretamente.

Sarlet ${ }^{19}$ informa que sessenta e cinco anos após a aprovação da Declaração Universal dos Direitos Humanos, em torno de cinquenta constituiçóes reconhecem o direito à moradia em seu texto legal, o que para um universo de cerca de duzentos Estados reconhecidos no mundo não parece ser tão expressivo.

Por outro lado, se tomar em conta que os direitos sociais têm sido reconhecidos em diferentes graus de fundamentalidade, em certos países desenvolvidos, a carência de condiçôes de moradia é fato absolutamente fora de contexto.

Já em outros países, imersos em profunda instabilidade político-institucional e econômica, ao contrário, a situação de desatendimento ao mínimo vital é tão preocupante que, temas como saúde, segurança, manutenção da ordem pública e educação se mostram tão incipientemente assegurados que, ainda, nem sequer se cogita atribuir status de direito fundamental à habitação.

17 "Art. 11, $\$ 1^{\circ}$. Os Estados-partes do presente Pacto reconhecem o direito de toda pessoa a um nível de vida adequado para si próprio e sua família, inclusive à alimentação, vestimenta e moradia adequadas, assim como uma melhoria contínua de suas condiçóes de vida. Os Estados-partes tomarão medidas apropriadas para assegurar a consecução desse direito, reconhecendo, nesse sentido, a importância essencial da cooperação internacional fundada no livre consentimento."

18 MilagreS, Marcelo de Oliveira. Direito à moradia. Sáo Paulo: Atlas, 2011, pp. 92-95.

19 SARLET, Ingo Wolfgang. Notas a respeito do direito fundamental à moradia na jurisprudência do Supremo Tribunal Federal. In: SARMENTO, Daniel; SARLET, Ingo Wolfgang (Coord.). Direitos fundamentais no Supremo Tribunal Federal: balanço e crítica. Rio de Janeiro: Lumen Juris, 2011. p. 690. 
A referência de cerca de 50 (cinquenta) estados constitucionais reconhecerem o direito à moradia passa a ser considerável, se examinada no cenário dos estados restantes resultantes da exclusão dos enquadrados nesses dois extremos:

A um, entre o acesso à moradia não constituir tema de maior preocupação ou tensão, porque o fato de ter onde morar dignamente já é realidade incorporada ao patrimônio jurídico da esmagadora maioria das pessoas.

A dois, de outra sorte, estados onde a falta de mínimas referências de habitabilidade em condiçóes de saúde, higidez e conforto convivem com estado de barbárie, tão caótico, que as mínimas noçôes de sobrevivência e integridade física assumem total proeminência, ao ponto de não se imaginar arguir um direito a prestações que ultrapasse a ordem pública mínima - asseguradora do direito à vida e de ir e vir, segundo modestas referências de liberdades civis e de prestaçôes mínimas de atendimento à saúde básica, quando se tem.

Assim, nos países de modernidade tardia, mas em processo de desenvolvimento econômico e institucional e, sobretudo, de inclusão social.

Por isso é que, Milagres ${ }^{20}$ informa que no âmbito da América Latina, enquadrados neste perfil, grande parte dos países contemplam a garantia do direito à moradia em seus textos constitucionais, como se verifica nas constituiçôes de Uruguai, México, Paraguai, Colômbia, Honduras e Nicarágua, em cujos textos figura a previsão de que - de uma forma ou de outra - "todos têm direito a uma moradia digna”.

A constituição do Equador menciona o "direito a uma moradia adequada e digna"; a da Bolívia, o "direito a uma moradia adequada"; as da Guatemala e da Costa Rica cuidam da proteção e do incentivo à construção de moradias populares, respectivamente.

Verifica-se, portanto, no cenário de pobreza latino-americano, a assunção em sede constitucional de compromisso expresso e explícito com a necessidade de promoção de políticas públicas e ações de governo e sociais - públicas e privadas, portanto - voltadas a garantir o direito social à moradia.

Milagres $^{21}$ agrega, nesse particular, também de modo específico, os paradigmas de Argentina, Costa Rica, Paraguai e México nos quais a tutela se projeta mais ampla, ao ponto de atribuir à moradia a natureza jurídica de bem de família, como se veio e se dar no Brasil.

A Constituição brasileira permite, em seu texto, correlacionar o direito social à moradia direta ou indiretamente com muitos dos princípios fundamentais da República, com locus topológico nos quatro primeiros artigos de seu texto.

20 MILAGRES, Marcelo de Oliveira. Direito à moradia. São Paulo: Atlas, 2011, p. 105-106.

21 MILAGRES, Marcelo de Oliveira. Direito à moradia. Sáo Paulo: Atlas, 2011, p. 106. 
O princípio da dignidade da pessoa humana (art. $1^{\circ}$, III $)^{22}$, assim como com os objetivos fundamentais da República (art. 30) ${ }^{23}$ de "construçáo de uma sociedade livre, justa e solidária” (Inc. I), "erradicação da pobreza e marginalização e redução das desigualdades sociais e regionais" (Inc. III) e, de certa forma, na opção pela prevalência dos direitos humanos fundamentais (art. $4^{\circ}$, inciso II) ${ }^{24}$, que, muito embora direcionada às relaçóes internacionais, traduz uma opção incondicional pela dignidade dos seres humanos.

$\mathrm{O}$ direito à moradia foi incorporado ao artigo $6^{025}$ da Constituição Federal, que faz parte do capítulo II, do título I, intitulado "Dos princípios fundamentais", por meio da Emenda Constitucional no 26, de 2000.

É importante ressaltar que tal direito já era mencionado em outros dispositivos constitucionais, tais como no artigo $7^{\circ}$, IV ${ }^{26}$, o qual define que o salário mínimo é aquele capaz de atender às necessidades vitais básicas do trabalhador e de sua família, dentre outros elementos, como moradia; e no artigo 23, IX ${ }^{27}$, quando dispóe sobre a competência comum da União, dos Estados, do Distrito Federal e dos Municípios para promover programas de construção de moradia e a melhoria das condiçóes habitacionais e de saneamento básico, segundo Sarlet ${ }^{28}$.

$\mathrm{Na}$ visão de $\mathrm{Campos}^{29}$, ar ser considerado um direito fundamental, o conteúdo material da norma que o disciplina seria de aplicação imediata e eficácia plena, À inteligência do parágrafo $1^{\circ}$, do artigo $5^{\circ 30}$ da Constituição Federal.

22 "Art. 1 A República Federativa do Brasil, formada pela união indissolúvel dos Estados e Municípios e do Distrito Federal, constitui-se em Estado Democrático de Direito e tem como fundamentos: (...) III - a dignidade da pessoa humana;"

23 "Art. 3o Constituem objetivos fundamentais da República Federativa do Brasil: I - construir uma sociedade livre, justa e solidária; II - garantir o desenvolvimento nacional; III - erradicar a pobreza e a marginalização e reduzir as desigualdades sociais e regionais; IV - promover o bem de todos, sem preconceitos de origem, raça, sexo, cor, idade e quaisquer outras formas de discriminação."

24 "Art. 40 A República Federativa do Brasil rege-se nas suas relaçóes internacionais pelos seguintes princípios: I - independência nacional; II - prevalência dos direitos humanos;"

25 "Art. 6o São direitos sociais a educação, a saúde, a alimentação, o trabalho, a moradia, o lazer, a segurança, a previdência social, a proteção à maternidade e à infância, a assistência aos desamparados, na forma desta Constituição." (Redação dada pela Emenda Constitucional nº 64, de 2010)

26 "Art. 70. São direitos dos trabalhadores urbanos e rurais, além de outros que visem à melhoria de sua condição social: (...) Inc. IV - salário mínimo, fixado em lei, nacionalmente unificado, capaz de atender a suas necessidades vitais básicas e às de sua família com moradia, alimentação, educação, saúde, lazer, vestuário, higiene, transporte e previdência social, com reajustes periódicos que lhe preservem o poder aquisitivo, sendo vedada sua vinculação para qualquer fim;"

27 "Art. 23, IX - promover programas de construção de moradias e a melhoria das condiçóes habitacionais e de saneamento básico;"

28 SARLET, Ingo Wolfgang. Notas a respeito do direito fundamental à moradia na jurisprudência do Supremo Tribunal Federal. In: SARMENTO, Daniel; SARLET, Ingo Wolfgang (Coord.). Direitos fundamentais no Supremo Tribunal Federal: balanço e crítica. Rio de Janeiro: Lumen Juris, 2011. p. 690.

29 CAMPOS, Núbia Carla. A efetividade do direito à moradia no judiciário brasileiro: uma análise comparativa da jurisprudência. 2011, 49. Monografia apresentada para conclusão da Escola de Formação da SBDP. Disponível em: <http://www.sbdp.org.br/monografias_ver.php?idConteudo=175>. Acesso em 21 fev. 2013.

30 "Art. $5^{\circ},(\ldots) \$ 1^{\circ}$ - As normas definidoras dos direitos e garantias fundamentais têm aplicação imediata." 
Rangel et Silva ${ }^{31}$ apoiam-se sobre o princípio da aplicabilidade imediata das normas definidoras de direitos fundamentais, para sustentarem dispensável regulamentação legislativa ulterior para lograr eficácia social.

Em que pese a superior relevância do direito à moradia e sua indeclinável natureza de direito fundamental social, faz-se necessário distinguir que os conteúdos dos princípios de aplicabilidade imediata e de eficácia plena compóem conceitos jurídicos eminentemente distintos, que não se igualam, nem se sobrepóem, tampouco se confundem: a aplicabilidade imediata decorre de previsão constitucional, que ratifica e recepciona a opção pelo efeito imediato - de retroatividade mínima, adotado desde a histórica Lei de Introdução ao Código Civil, hoje, Lei de Introdução ao Direito Brasileiro, a conceber a vigência imediata, "no que couber" a qualquer dispositivo veiculador de direitos fundamentais.

A doutrina constitucional brasileira e a jurisprudência do STF já tornaram assente que a limitação daquilo que é "cabível", em termos de "aplicação imediata" dos direitos fundamentais, se dá a partir da própria arquitetura adotada por cada dispositivo do texto constitucional. Esse modelo é consagrado por diversas classificaçóes de normas constitucionais, em torno das ideias de eficácia plena, eficácia contida e eficácia limitada, com suas nuances, caso a caso, conforme tão bem explicitam os doutrinadores José Afonso da Silva, Luis Roberto Barroso e Maria Helena Diniz, dentre outros de relevo reconhecido.

O Estatuto da Cidade ${ }^{32}$ (Lei no 10.257/2001) refere-se explicitamente ao direito à moradia a partir da adoçáo de princípios e diretrizes, fundados no que denomina princípio instrumental do planejamento, segundo Rangel et Silva ${ }^{33}$, voltado a conferir contornos de sustentabilidade ao direito à moradia no espaço urbano, com o intuito de regulamentar a política urbana nacional.

Mais que isso, o referido estatuto adotou o instituto do plano diretor, com o intuito de viabilizar um planejamento lógico e funcional do espaço urbano, em benefício de seus ocupantes e da sociedade como um todo.

31 RANGEL, Helano Márcio Vieira et SILVA, Jacilene Vieira da. O direito fundamental à moradia como minimo existencial, e a sua efetivação à luz do Estatuto da Cidade. Veredas do Direito, Belo Horizonte, v. 6, p. 57 - 78, jul.-dez. 2009 , pp. 67 e 68.

32 Lei ordinária federal que regulamenta os arts. 182 e 183 da Constituiçấo da República Federativa do Brasil, estabelece diretrizes gerais da política urbana e dá outras providências.

33 RANGEL, Helano Márcio Vieira et SILVA, Jacilene Vieira da. O direito fundamental à moradia como minimo existencial, e a sua efetivação à luz do Estatuto da Cidade. Veredas do Direito, Belo Horizonte, v. 6, p. 57 - 78, jul.-dez. 2009, p. 72. 


\section{Evolução das Políticas Públicas Habitacionais no Brasil}

Nogueira $^{34}$ associa inicialmente a má distribuição da terra no Brasil ao período colonial português que, historicamente, teria contribuído a partir do sistema de "capitanias hereditárias" para a injustiça distributiva, pela distribuição de sesmarias pelo coroa lusitana a determinados donatários escolhidos pelo rei. Isto, claro restou como nada mais subjetivo, nepótico, pessoal e, portanto, dissociado do ideal de justiça, ainda que se utilizasse qualquer critério de mérito em relação aos seus destinatários.

Por outro lado, analisando com maior cuidado as críticas que buscam compreender o processo de concentração de propriedade no Brasil, embora se possa reconhecer que a instituição e consolidaçáo da prática de concessóes de terras tenham se dado de forma absolutamente descompromissada de qualquer ideal de justiça social distributiva, é preciso situar os fatos no tempo e no espaço, já que, na realidade do século XVII (e seguintes), não se identificava, ainda, o reconhecimento a direitos fundamentais nem mesmo civis, que dirá sociais, o que só, em termos europeus se inauguraria com o advento da revolução francesa e a Declaração dos Direitos do Homem e do Cidadão, mas nas colônias ainda levaria muitos anos; portanto, fica a questão: como cotejar a práxis política colonial com os ideais constitucionais democráticos, hoje vigentes, de justiça social?

Por isso, a iniciativa do rei de Portugal Dom Manuel - chamado “o venturoso" - de repartir o território da colônia brasilis em 13 capitanias para fins de concessão descentralizadora, - chamadas "hereditárias", pois uma vez outorgadas, teriam tradição jus sanguinis dos seus originais donatários aos herdeiros -, baseou a ocupação territorial no princípio do uti possidetis, ou seja, da "posse útil", exigindo dos beneficiários que promovessem o povoamento e o desenvolvimento de atividades econômicas, a fim de conferir alguma efetividade ao processo de ocupação territorial naquele momento político histórico.

Tratava-se de espécie de assinatura estimuladora ao desenvolvimento do Brasil colônia por áreas, com especial foco nas menos desenvolvidas, ou seja, por meio da posse útil - em muito relacionada com o uso dado à terra objeto da concessão.

Se observada a extensão do território sob a gestão portuguesa, mesmo limitado pelo - à época vigente - tratado de Tordesilhas, cujo meridiano corta onde hoje correspondem, ao norte, à cidade de Belém do Pará (Estado do Pará) e, ao sul, a de Laguna (Estado do Paraná), tem-se a noção de muita extensão de terra distribuída a poucos, sem dúvida.

O que não se pode perder de vista é que essa crítica se perde em si mesma porque é descontextualizada, já que o sistema de capitanias não funcionou adequadamente,

34 NOGUEIRA, Joilma Sampaio. Politicas públicas de habitação no Brasil: uma análise do Programa de Urbanização e Regularização de Assentamentos Precários no Município de Santo Antônio de Jesus - BA. Faculdade Adventista da Bahia, Cachoeira, 2010, p. 7. 
registrando apenas o sucesso de duas delas: São Vicente e Itamaracá (correspondentes a um trecho do estado de São Paulo e ao estado de Pernambuco), sendo a seguir extintas, portanto, não prevalecendo como elemento causador de uma real distribuiçáo injusta de terras.

O recurso ao estudo desse momento histórico trata-se, quando muito, de elemento inspirador da noção de concentração de terras em poucas mãos, mas não de um componente fático do fenômeno latifundiário, ao "sugerir" às gerações futuras uma distribuição desigual de extensas áreas a poucos, mas não que se possa associá-la com efeitos reais, porque tal arranjo foi desfeito pela adoção do sistema dos "Governos-gerais", no Brasil, com a capital em Salvador. Assim, não há nexo causal entre o fato histórico e a realidade atual, embora ambos sejam verdadeiros.

Durante o período colonial, diversos ciclos econômicos tais como o da exploração do ouro, das pedras preciosas, das drogas do sertáo e da criação de gado, dentre outros, todos embalariam os interesses políticos e econômicos, justificando, aí sim, o processo de concentração de riqueza, como ocorrido em outras áreas do planeta, sujeitas a processos semelhantes, tal como ocorreu na expansão territorial dos Estados Unidos da América.

A título de registro pontual, conta-se que a transferência da família real para o Brasil, em 1808, - motivada pela iminente entrada das tropas de Napoleão em Lisboa - fez migrar para cá, não só o escalão governamental português, mas relevante volume de fidalgos, familiares e criadagem, provocando casos de tensão social originados pela deficiência habitacional, já que para suprirem suas necessidades imediatas, as "autoridades" portuguesas decidiram por expropriar os proprietários de imóveis que selecionaram, na cidade do Rio de Janeiro, para abrigar a recém-chegada Corte portuguesa.

Com a ocorrência de tantos desapossados para atender aos novos "hóspedes" da cidade, marcou-se como episódio com a aplicação da sigla "PR" que representava uma espécie de "decreto expropriatório" - e oficialmente se referia à expressão "Príncipe Regente" - logo convertida pelo espírito crítico carioca em: "Prédio Roubado" ou "Ponha-se na Rua”.

O subsequente período imperial contribuiria para consolidar um processo de concentraçáo de renda e de propriedades nas mãos de uma elite portuguesa, escravocrata, envolvida nas atividades econômicas de produção de commodities, tais como os chamados ciclos da cana e do café, por exemplo, que, apoiados na legalidade e na contratualidade civilista acentuaram a tendência à concentração da propriedade na classe mais rica.

Com a República, o desenvolvimento de uma população urbana pré-industrial, e, depois industrial, iria deflagrar um processo de reconhecimento da anunciada concentração da propriedade e decorrente carência habitacional para a classe assalariada. 
De acordo com Motta ${ }^{35}$, no primeiro quartel do século XX, o problema da habitação foi intensificado em muitas cidades brasileiras, notadamente nos grandes centros econômicos, pois o poder público náo se via preparado estrategicamente para a nova realidade do país, primeiro pela aboliçáo da escravatura, em 1888, que deixara uma grande contingente populacional formado por escravos recém libertados, deixados a sua própria sorte, sem qualquer perspectiva habitacional, quadro a seguir agravado pela introdução de migrantes e mesmo de respeitável efetivo imigrantes, trazidos das mais diversas origens para recompletamento dos efetivos de mão de obra liberta, necessários à agricultura e à transição industrializante.

Botega ${ }^{36}$ apresenta dados dos censos demográficos do Instituto Brasileiro de Geografia e Estatística (IBGE) demonstradores da influência do período de industrialização no Brasil para o aumento significativo da população urbana, dos quais se depreende que, em 1920, a proporção urbana representava 11,3\% (onze vírgula três pontos percentuais) e, já em 1950 , superava a população rural em 55,9\% (cinquenta e cinco vírgula nove pontos percentuais).

Assim, a falta de alternativas habitacionais, o intenso processo de industrialização e a baixa renda das famílias contribuíram para que uma grande parcela da população brasileira buscasse alternativas precárias e informais para morar, caracterizadas pela falta de acesso a serviços, assistência de infraestrutura, informalidade na posse da terra, entre outros, segundo fonte ministerial ${ }^{37}$.

Segundo Nogueira ${ }^{38}$, nesse período republicano anterior à era Vargas, as moradias foram resultado de açóes da iniciativa privada e do autofinanciamento, até a criação da Fundação da Casa Popular (FCP) em 1946, órgão federal responsável pelo financiamento da construção de habitaçóes e que, ao mesmo tempo, apoiava a indústria de materiais de construção e a implementação de projetos de saneamento; a Fundação da Casa Popular foi a primeira ação do governo destinada à questão da habitação, promulgada pelo Presidente Eurico Gaspar Dutra, por meio do Decreto-Lei no 9.777, de 6 de setembro de 1946 e tinha o compromisso de prover residências para a população de baixa renda, mas, seus resultados foram modestos, tendo criado apenas dezessete mil moradias, no espaço temporal de vinte anos de atuação, sendo extinta em 1964, conforme relata Motta ${ }^{39}$.

35 MOTTA, Luana Dias. A questäo da habitação no Brasil: políticas públicas, conflitos urbanos e o direito à cidade. 2011.Acesso em 16 fev. 2013. Disponível em: <http://conflitosambientaismg.lcc.ufmg.br >.

36 BOTEGA, Leonardo da Rocha. A Política Habitacional no Brasil (1930-1990). Revela -Revista Eletrônica Acadêmica da FALS, ano I, n. 2, mar. 2008, p. 4.

37 Dados do período de 1940 a 2000. Ministério das Cidades, 2009, p. 36.

38 NOGUEIRA, Joilma Sampaio. Politicas públicas de habitação no Brasil: uma análise do Programa de Urbanização e Regularização de Assentamentos Precários no Município de Santo Antônio de Jesus - BA. Faculdade Adventista da Bahia, Cachoeira, 2010, p. 7.

39 MOTTA, Luana Dias. A questão da habitação no Brasil: políticas públicas, conflitos urbanos e o direito à cidade. 2011.Acesso em 16 fev. 2013. Disponível em: <http://conflitosambientaismg.lcc.ufmg.br>. 
Com a criação do Sistema Financeiro de Habitação (SFH) e do Banco Nacional de Habitação (BNH) pelo advento da Lei no 4.380/64, alterada pela Lei no 5.049/66, ambas promulgadas pelo presidente Humberto de Alencar Castello Branco - tem-se marco significativo da intervenção do Estado no setor habitacional, bem anota Nogueira ${ }^{40}$. Para Motta $^{41}$, o Plano Nacional de Habitação ${ }^{42}$ e o Sistema Financeiro de Habitação visavam outros objetivos além ampliar a oferta de habitação, tais como a dinamização da economia e o desenvolvimento do país, todos ícones do governo militar.

Conforme Nogueira ${ }^{43}$ e Medeiros ${ }^{44}$, as fontes de recurso advinham da arrecadação decorrente do Sistema Brasileiro de Poupança e Empréstimos (SBPE), por meio da captação das letras imobiliárias e cadernetas de poupança, e, a partir de 1967, passaram a contar também com o Fundo de Garantia por Tempo de Serviço (FGTS), resultado das contribuiçóes compulsórias com base em $8 \%$ (oito pontos percentuais) dos salários dos trabalhadores empregados formais do mercado de trabalho. A destinação da arrecadação do FGTS fora destinada inicialmente à construção de casas de interesse social, como conjuntos populares, mas, posteriormente diversificou-se também para os setores de saneamento e desenvolvimento urbano.

Medeiros $^{45}$ assinala que os recursos gerados pelo FGTS deveriam ser destinados ao financiamento de obras para a população de baixa renda, enquanto que a arrecadação do SBPE financiaria obras direcionadas às classes média e superior. Entre 1964 e 1965 foram criadas as Companhias de Habitação Popular (COHABs), que eram empresas públicas ou de capital misto, cujo principal objetivo era atuar na criação e execução de políticas para reduzir o déficit habitacional por meio do financiamento de moradias para o mercado popular, conforme o Relatório Motta ${ }^{46}$.

Sobre o Banco Nacional da habitação $(\mathrm{BNH})$, Nogueira ${ }^{47}$ ressalta que a instituição não chegou a viabilizar efetivamente o acesso da população de baixa renda

40 NOGUEIRA, Joilma Sampaio. Políticas públicas de habitação no Brasil: uma análise do Programa de Urbanização e Regularização de Assentamentos Precários no Município de Santo Antônio de Jesus - BA. Faculdade Adventista da Bahia, Cachoeira, 2010, p. 7.

41 MOTTA, Luana Dias. A questão da habitação no Brasil: políticas públicas, conflitos urbanos e o direito à cidade. 2011.Acesso em 16 fev. 2013. Disponível em: <http://conflitosambientaismg.lcc.ufmg.br>.

42 Operado pelo Banco Nacional da Habitação (BNH).

43 NOGUEIRA, Joilma Sampaio. Políticas públicas de habitação no Brasil: uma análise do Programa de Urbanizaçāo e Regularização de Assentamentos Precários no Município de Santo Antônio de Jesus - BA. Faculdade Adventista da Bahia, Cachoeira, 2010, p. 8.

44 MEDEIROS, Sara Raquel Fernandes Queiroz de. BNH: outras perspectivas. 2010, p. 4. Disponível em: <http://www.cchla.ufrn.br>. Acesso em 27 fev. 2013.

45 Ibid.

46 MOTTA, Luana Dias. A questão da habitação no Brasil: políticas públicas, conflitos urbanos e o direito à cidade. 2011.Acesso em 16 fev. 2013. Disponível em: <http://conflitosambientaismg.lcc.ufmg.br>.

47 NOGUEIRA, Joilma Sampaio. Politicas públicas de habitação no Brasil: uma análise do Programa de Urbanização e Regularização de Assentamentos Precários no Municipio de Santo Antônio de Jesus - BA. Faculdade Adventista da Bahia, Cachoeira, 2010, p. 9. 
a empréstimos, facilitando o crescimento do número de habitaçóes informais, o que teria motivado a criação dos programas habitacionais: PROFILURB, PROMORAR e João de Barro, destinados à população de renda inferior a três salários mínimos, faixa em que se sistematicamente se concentrou a maior gravidade do problema habitacional brasileiro.

O Programa de Financiamento de Lotes Urbanizados (PROFILURB), criado em 1975, também assinalou por meta atender aos extratos mais baixos de renda familiar, com o fito de erradicar favelas e de incentivar o financiamento de lotes urbanizados, ou seja, com infraestrutura básica dotada de ponto de água, luz e ligação de coleta de esgoto, com ou sem a unidade sanitária, segundo Bueno ${ }^{48}$. Os lotes variavam de 80 a $370 \mathrm{~m}^{2}$, financiados em prazo máximo de vinte e cinco anos, com taxas de juros anuais bem favoráveis, oscilando entre $2 \%$ e $5 \%$ (dois e cinco pontos percentuais) e, assim, facilitou, de certa forma, o acesso à terra e a construção da moradia pelos mutuários.

Bueno $^{49}$ informa que o Programa de erradicação da sub-habitação (PROMORAR), implantado em 1979, teve por finalidade prevenir o crescimento de favelas nos grandes centros urbanos, possibilitando a aquisição de moradas de pequena extensão (até $24 \mathrm{~m}^{2}$ ), mediante financiamento, por prazo máximo de até 30 (trinta) anos, aplicando taxas de juros anuais máximas de $2 \%$ (dois pontos percentuais).

Medeiros $^{50}$ ressalta que foi a primeira ação em que não se buscou remover os moradores, mas fixá-los no núcleo originalmente invadido de terra. Realizado por construtoras, esse programa financiou cerca de duzentos e seis mil moradias em todo o país até 1984, contabilizando o triplo de unidades a mais que o PROFILURB, conforme consta da pesquisa de Bueno ${ }^{51}$.

O Programa João de Barro, criado em 1982, no contexto do "processo de abertura política” e diante de severa crise econômica, propugnava pelo acesso à moradia, financiando o terreno e o material de construção, contando com a participação da coletividade e focava com prioridade as cidades do interior e destinando-se às famílias com renda de até três salários mínimos. Segundo Bueno ${ }^{52}$, o programa disponibilizou financiamentos em prazo máximo de 30 (trinta) anos, com taxas de juros anuais de $2 \%$ (dois pontos percentuais),

48 BUENO, Laura Machado Mello. Projeto e favela: metodologia de projeto de urbanização de favelas. Tese (Doutorado em Arquitetura e Urbanismo) - Universidade de São Paulo, São Paulo, 2000, p. 30.

49 BUENO, Laura Machado Mello. Projeto e favela: metodologia de projeto de urbanização de favelas. Tese (Doutorado em Arquitetura e Urbanismo) - Universidade de São Paulo, São Paulo, 2000, p. 31.

50 MEDEIROS, Sara Raquel Fernandes Queiroz de. BNH: outras perspectivas. 2010, p. 5. Disponível em: $<$ http://www.cchla.ufrn.br>. Acesso em 27 fev. 2013.

51 BUENO, Laura Machado Mello. Projeto e favela: metodologia de projeto de urbanização de favelas. Tese (Doutorado em Arquitetura e Urbanismo) - Universidade de São Paulo, São Paulo, 2000, p. 30.

52 BUENO, Laura Machado Mello. Projeto e favela: metodologia de projeto de urbanização de favelas. Tese (Doutorado em Arquitetura e Urbanismo) - Universidade de São Paulo, São Paulo, 2000, p. 32. 
mas obteve pouca eficiência, com apenas sete mil unidades produzidas até 1984, concentradas em cidades do interior da região nordeste brasileira.

No âmbito do Sistema Financeiro de Habitação, o Banco Nacional da Habitação foi o principal órgão da política habitacional, na visão de Motta ${ }^{53}$, cabendo-lhe orientar, disciplinar e controlar a atuação do Sistema Financeiro da Habitação na construção e aquisição da casa própria para população de baixa renda. Medeiros ${ }^{54}$ agrega que, além de ter um objetivo social, o Banco Nacional da Habitação também buscou incentivar a economia por meio da expansão da ocupação da mão de obra na construção civil.

Nogueira $^{55}$, por sua vez, atribui aos índices de inflação extremamente elevados na década de 1980, - quando chegou a ser registrada inflação de 80,0\% ao mês -, a derrocada do Sistema Brasileiro de Poupança e Empréstimo e principalmente do Banco Nacional de Habitação pela intensa e insustentável inadimplência. $\mathrm{O}$ fenômeno se caracterizou por um reajuste superior nas prestaçóes dos financiamentos imobiliários das classes média e alta em comparação com seus índices de reajuste salarial.

Nesse contexto, segundo Botega ${ }^{56}$, em 1986, deu-se a extinção do Banco Nacional da Habitação, pelo Decreto no 2.291, com a transferência de suas atribuições e funções para a Caixa Econômica Federal. A Política Nacional de Habitação, a crise do Sistema Financeiro Habitação e a extinção do Banco Nacional da Habitacional criaram solução de continuidade, deixando um hiato na política habitacional no país, com significativa redução dos recursos destinados a investimentos na área de construção civil e consequente fragmentação institucional por perda da capacidade decisória.

Já no ambiente de redemocratização do Brasil, a Secretaria Especial de Ação Comunitária criou o Programa Nacional de Mutiróes Habitacionais (1987), destinado a financiar moradias para famílias com renda inferior a três salários mínimos e coordenar programas de obras de infraestrutura, regularização fundiária em favelas, construção de habitaçóes em regime de mutirão e instalação de equipamentos comunitários em favelas, também não apresentando resultados expressivos, conforme a pesquisa de Bueno ${ }^{57}$.

53 MOTTA, Luana Dias. A questão da habitação no Brasil: políticas públicas, conflitos urbanos e o direito à cidade. 2011.Acesso em 16 fev. 2013. Disponível em: <http://conflitosambientaismg.lcc.ufmg.br>.

54 MEDEIROS, Sara Raquel Fernandes Queiroz de. BNH: outras perspectivas. 2010, p. 3. Disponível em: $<$ http://www.cchla.ufrn.br>. Acesso em 27 fev. 2013.

55 NOGUEIRA, Joilma Sampaio. Políticas públicas de habitação no Brasil: uma análise do Programa de Urbanização e Regularização de Assentamentos Precários no Município de Santo Antônio de Jesus - BA. Faculdade Adventista da Bahia, Cachoeira, 2010, p. 8.

56 BOTEGA, Leonardo da Rocha. A Política Habitacional no Brasil (1930-1990). Revela -Revista Eletrônica Acadêmica da FALS, ano I, n. 2, mar. 2008, p. 10.

57 BUENO, Laura Machado Mello. Projeto e favela: metodologia de projeto de urbanização de favelas. Tese (Doutorado em Arquitetura e Urbanismo) - Universidade de São Paulo, São Paulo, 2000, p. 34. 
Para Nogueira ${ }^{58}$, nos anos de 1990 e 1991, a gestáo de políticas públicas habitacionais foi reestruturada, ampliando-se significativamente o controle social e a transparência da gestão de programas por exigir a participação comunitária. O que se deu por meio de conselhos e dos governos municipais, de poder local, além de uma contrapartida financeira.

Botega $^{59}$ assenta que, pelos dados do Instituto Brasileiro de Geografia e Estatística, de 1991, o número de moradores de rua chegava há sessenta milhões de pessoas e que $55,2 \%$ (cinquenta e cinco pontos vírgula dois pontos percentuais) das famílias se encontravam em déficit habitacional.

Bueno $^{60}$ explica que a década de 1990 se caracterizou como período de grande conturbação política e de muitas mudanças na estrutura institucional da gestão da problemática de estrutura urbana, habitacional e social.

O período de 1990 a 1992 representou a adoção de diversos programas habitacionais, mas o que teve alguma expressão foi o Plano de Ação Imediata para a Habitação (PAIH), que previu o financiamento de duzentos e quarenta e cinco mil casas em cento e oitenta dias, por meio da contratação de construtoras, conforme bem registra Bueno ${ }^{61}$.

Botega $^{62}$, entretanto, ressalva que o prazo inicial se estendeu por mais de dezoito meses, aumentando o custo médio inicialmente previsto e diminuindo o número de moradias construídas para duzentos e dez mil.

Motta $^{63}$ informa que no período de 1992 a 1994, foram criados dois programas voltados à questão da habitação, o "Habitar Brasil" e o "Morar Município", que buscaram financiar obras e açóes nos municípios e capitais de estados ou integrantes de regiôes metropolitanas e aglomerados urbanos voltados para a população de baixa renda com renda familiar de até três salários mínimos; nesse contexto, entretanto, o excesso de exigências legais restringiu em muito a captação de recursos postos à disposição dos municípios.

Bueno $^{64}$ destaca que, apesar dos resultados pouco expressivos aproximadamente dezoito mil unidades construídas até 1994, os referidos programas tiveram sua importância no sentido de reformular o pensamento nacional quanto à política habitacional.

58 NOGUEIRA, Joilma Sampaio. Politicas públicas de habitação no Brasil: uma análise do Programa de Urbanização e Regularização de Assentamentos Precários no Município de Santo Antônio de Jesus - BA. Faculdade Adventista da Bahia, Cachoeira, 2010, p. 10.

59 BOTEGA, Leonardo da Rocha. A Política Habitacional no Brasil (1930-1990). Revela -Revista Eletrônica Acadêmica da FALS, ano I, n. 2, mar. 2008, pp. 12-13.

60 BUENO, Laura Machado Mello. Projeto e favela: metodologia de projeto de urbanizaçāo de favelas. Tese (Doutorado em Arquitetura e Urbanismo) - Universidade de São Paulo, São Paulo, 2000, p. 33.

61 Ibid.

62 BOTEGA, Leonardo da Rocha. A Política Habitacional no Brasil (1930-1990). Revela -Revista Eletrônica Acadêmica da FALS, ano I, n. 2, mar. 2008, p. 12.

63 MOTTA, Luana Dias. A questão da habitação no Brasil: políticas públicas, conflitos urbanos e o direito à cidade. 2011.Acesso em 16 fev. 2013. Disponível em: <http://conflitosambientaismg.lcc.ufmg.br>.

64 BUENO, Laura Machado Mello. Projeto e favela: metodologia de projeto de urbanização de favelas. Tese (Doutorado em Arquitetura e Urbanismo) - Universidade de São Paulo, São Paulo, 2000, p. 34. 
Entre 1994 e 2002, várias reformas do setor habitacional se mostraram efetivas, promovendo uma reorganização do aparato institucional referente à Caixa Econômica Federal, com sua atuação limitada a agente operador dos recursos do Fundo de Garantia por Tempo de Serviço e agente financeiro do Sistema Financeiro da Habitação. Com isso, criaram-se novas linhas de financiamento, baseadas em projetos dos governos estaduais e municipais.

Criou-se o Programa de Arrendamento Residencial (PAR), que atuou na construção de novas unidades para arrendamento, utilizando recursos principalmente formados pelo FGTS e de origem fiscal ${ }^{65}$.

Pode-se relacionar, segundo Bueno ${ }^{66}$, o Programa Construcard, como iniciativa de direito privado, operado pela Caixa Econômica Federal (empresa pública federal), portanto, protagonizado pela administração pública federal, mas no âmbito da economia de mercado, é voltado a auxiliar na compra de materiais de construção, por meio de financiamento direto, por juros menores que os praticados no mercado bancário.

$\mathrm{Na}$ verdade, essa linha de financiamento auxiliar, embora conveniente aos interesses de alguns, não chega a promover uma alteração concreta na realidade habitacional, quando muito oferecendo alguma facilidade para melhoria de moradias, mas sem qualquer resultado expressivo em termos de política habitacional.

A criação do Ministério das Cidades, em 2003, voltado à política urbana e às políticas setoriais de habitaçáo, saneamento e transporte veio a complementar o esforço de regulamentação das atividades de organização e utilização do espaço urbano, visando a reduzir os óbices decorrentes da ausência ou da descontinuidade de estratégias em termos de políticas urbanas, passando a exercer o papel de órgão coordenador, gestor e formulador da Política Nacional de Desenvolvimento Urbano e, em escala circunscrita, da própria Política Nacional de Habitação.

Azevedo $^{67}$ registra que a lei federal $n^{0} 11.124 / 2005$, que trata do Sistema Nacional de Habitação de Interesse Social (SNHIS), criou o Fundo Nacional de Habitação de Interesse Social (FNHIS), a fim de garantir o acesso à habitação digna para população de menor renda, pela implantação de políticas e programas de investimento e subsídios. A lei $n^{\circ} 11.888 / 2008$, que assegurou às famílias de menor poder aquisitivo assistência pública para a construção de moradias de interesse social.

Também como medida atual e, ainda objeto de monitoramento e avaliação, enquanto política pública, o programa "Minha casa, minha vida", de iniciativa federal, foi implantado em 2009 pela Medida Provisória no 459/2009, mais tarde convertida

65 Ministério das Cidades, 2009, p. 42.

66 Ibidem.

67 Instituto de Pesquisa Econômica Aplicada, 2012, p. 3. 
na Lei $n^{\circ} 11.977 / 2009$ e alterada pela MP no 514/2010, também convertida na Lei $n^{\circ}$ $12.424 / 2011$, tem por meta construir um milhão de casas, com previsão de alocação de 34 bilhôes de reais $(\mathrm{R} \$)$ em recursos para a construção e financiamento para famílias de renda de até dez salários mínimos e pretende estimular também a criaçáo de empregos e de investimentos no setor da construção civil, registra Motta ${ }^{68}$.

Conforme assenta Nogueira ${ }^{69}$, a este se pode associar o Programa de Aceleração do Crescimento (PAC) - também federal - cuja finalidade é de atender às necessidades de desenvolvimento das regióes metropolitanas, aglomerados urbanos e cidades com mais de 150 mil habitantes. Problema que não pode ser olvidado é que a competência para a construção de moradias é comum ${ }^{70}$ a todos os entes da federação, mas a União detém o protagonismo centralizador, por vezes responsável por engessar o processo em demasia.

Pode-se verificar que muitas foram as iniciativas governamentais sob a forma de políticas públicas, voltadas a superar o déficit de oferta de moradia de baixo custo e mesmo à classe média. Entretanto, verifica-se, também, que, em regra, os objetivos foram sistematicamente superdimensionados e, por isso mesmo, deixaram de ser alcançados de forma expressiva.

Identifica-se, portanto, que a profusão de políticas públicas subsequentes não tem sido eficiente como solução definitiva ao problema de moradia, por vezes fruto de um otimismo equivocado, por outras de um oportunismo eleitoral, e mesmo, obstaculizado pelas naturais dificuldades estruturais e conjunturais, mas, independentemente, da razão, a escolha de objetivos menos prioritários e técnicas pouco eficazes no tocante à reduçáo do déficit de moradias.

Outro complicador que merece ser registrado é o contínuo fluxo migratório interno, entre as regióes brasileiras menos desenvolvidas e as mais, de pessoas em busca de trabalho e de opçóes de vida digna, em termos de prestaçóes sociais e oportunidades pessoais, que realimenta o desequilíbrio na direção da falta de moradia, pois todos os dias aportam milhares de brasileiros vindos das regiôes menos desenvolvidas para instalar-se nos grandes centros atraídos por uma esperança de vida mais confortável e de melhores oportunidades profissionais, o que faz com que o déficit imobiliário só se multiplique dia após dia.

Falta, portanto, uma política de informação e esclarecimento que busque eficazmente orientar as pessoas que se encontram em desencanto com suas áreas de origem sobre as

68 MOTTA, Luana Dias. A questão da habitação no Brasil: políticas públicas, conflitos urbanos e o direito à cidade. 2011.Acesso em 16 fev. 2013. Disponível em: <http://conflitosambientaismg.lcc.ufmg.br>.

69 NOGUEIRA, Joilma Sampaio. Politicas públicas de habitação no Brasil: uma análise do Programa de Urbanização e Regularização de Assentamentos Precários no Município de Santo Antônio de Jesus - BA., Faculdade Adventista da Bahia, Cachoeira, 2010, p. 2.

70 "Art. 23. É competência comum da União, dos Estados, do Distrito Federal e dos Municípios: (...) IX - promover programas de construçấo de moradias e a melhoria das condiçôes habitacionais e de saneamento básico;" 
reais possibilidades de êxito nesses projetos pessoais migratórios, de forma a desestimular o inchamento das metrópoles, muito especialmente porque financiar construçóes em cidades menores tem um custo muito inferior ao de fazê-lo em áreas super-habitadas, com custos forçados pela especulação imobiliária.

Com isso, certamente, se reduziria certamente um dos fatores responsáveis pela grande concentração populacional nos grandes centros e fator de pressão social habitacional, que finda por forçar a expansão de moradias sub-humanas. A incapacidade de pagamento dos financiamentos, em razão da desproporção entre os altos custos atuariais e a baixa renda de grande parte da população mutuaria se constitui em fator de pressão negativa.

\section{Conclusões}

Depreende-se que a Constituição brasileira se mostra rica de previsóes sobre a fundamentalidade de diversos direitos incluídos no patrimônio jurídico dos cidadãos. Desde os mais basilares e instintivos ou intuitivos direitos individuais aos complexos direitos difusos, da mais sofisticada concepção, extenso é o rol de direitos, que claramente prestigiam as tutelas prestacionais dos direitos sociais, a saber, direitos tais como: saúde, transporte, educação, moradia, previdência e assistência sociais, dentre tantos outros.

Os estudos de direitos sociais são recorrentes em apontar como óbices a sua efetiva realização, alguns componentes, tais como a baixa normatividade, associada à arquitetura inspirada em critérios de programaticidade; nesse jaez, o ponto central não será mais repetir a existência desse problema, mas apontar eventuais formas de resolvê-lo.

Ausente a positivação, ou se sustenta que ela é desnecessária, por meio de bons argumentos principiológicos, de ordem pós-positivista ou aponta-se quem são os responsáveis por suprir a carência legislativa; no exemplo, como cabe ao Poder Legislativo prover a competente positivação dessas normas, então, uma vez identificado como responsável pela ação de política faltante (União, estado, Distrito Federal ou município), passa-se a desferir sobre o ator silente os estímulos hábeis a romper-lhe a inércia, sejam eles políticos, sociais ou jurídicos, se couberem.

O discurso de efetivar direitos sociais, portanto, ultrapassa em muito o debate material acerca tão somente da natureza desses direitos, a dizer: sua resistida fundamentalidade e sua força cogente como direitos subjetivos, exigíveis em razão do dever constitucional; a coercitividade e o compromisso moral das constituições dirigentes, a lacunosa positivação desses direitos, o déficit de financiamento orçamentário - com a contraposição das teorias de máxima efetividade da Constituição, de reserva do possível ou de mínimo existencial.

É verdade, sim, que todas essas provocaçôes se revestem da maior importância, mas, segundo uma visão pragmática, a efetivação dos direitos sociais vai para além de demonstrar 
a sua existência, apresentar suas classes e sustentar sua cogência como direitos subjetivos. Necessário se faz enfrentar os mecanismos de efetivação e, nesse particular, segundo a visão processual, definir quem deve ser instado a cumprir tal ônus político e, se não cumprido, responder pelo dever jurídico.

A fim de responder pelo atendimento das necessidades dos cidadãos em termos de políticas sociais - de cunho prestacional de direitos sociais, a Carta Republicana estabeleceu uma repartição de atribuiçóes, organizacionais, governamentais, legislativas e administrativas a cada um dos componentes do complexo chamado Estado.

Portanto, faz-se necessário dominar o conhecimento dessa intrincada estrutura estatal de governo e de administração pública, em seus variados matizes, a começar por seus agentes, pessoas e órgãos, de modo a bem estabelecer as particularidades entre cada um deles e poder deles retirar o melhor em termos de vocação institucional como atores de políticas públicas.

A vocação democrática do Pacto Federativo Brasileiro, detentor de uma arquitetura das mais arrojadas, com um elevado grau de abertura e visão inclusiva extremamente plural se fazem reconhecer hoje com amplitude sem precedente.

Neste mister, o estudo da equação da distribuição de competências pelo texto constitucional se faz basilar e de importância central, e comparativamente se mostrou bem amplificado em relação às constituiçóes que se lhe fazem anteceder, proporcionando uma evolução de um federalismo nominal para um federalismo efetivo e normativo.

Da mesma forma, se desvelada a limitação de ordem financeira ou orçamentária que inviabiliza o atendimento de um direito social tido como dotado de força subjetiva e, portanto, exigível, identifique-se quem detém a competência para provera prestaçáo.

Igualmente, projetem-se contra o ator omisso as açóes de ordem efetivadora, seja por via de pressão política - via sociedade civil, seja por pressão jurisdicional, via açôes constitucionais competentes.

Para tanto, necessário se faz bem identificar quem figurará no polo passivo: a União, o estado, o município, o Distrito Federal, o patronato, o terceiro setor detentor de concessóes, o empresário ou a sociedade, sob pena de extinção do processo por carência das condições da ação, a saber: a legitimidade passiva.

Constando a prestação faltante do rol de competências comuns ou concorrentes, a ideia geral de federação por cooperação entre os entes federados se apresenta como verdadeiro dever de Estado e autoriza a parte a parte exigir - em termos subjetivos - a prestação pelos entes alcançados em termos de competências comuns (administrativas) e concorrentes (legislativas).

Deve-se, contudo, avaliar a conveniência ou eventual obrigatoriedade em constituir o litisconsórcio (facultativo ou necessário), devendo-se aferir se a eventual presença de um 
ou outro ente no polo passivo irá contribuir para a efetivação da tutela ou, ao contrário, por absurdo, irá processualmente beneficiar aos réus, disponibilizando fartas oportunidades para dilação de prazos e emprego de movimentos protelatórios.

Em outras palavras: se os atores de políticas públicas - seus responsáveis - não estiverem claramente identificados, será necessário explicitá-los, seja na esfera pública, no âmbito mencionado genericamente Estado; seja na esfera privada, no âmbito da sociedade brasileira. É preciso definir mais claramente quem deve responder pelo que, em cada passo do desenvolvimento e aplicação das políticas sociais.

Por isso, faz-se indispensável a detenção de uma noção mais densa acerca da órbita federativa, para que, se compreenda melhor a distribuição de competências e atribuiçóes de cada nível de estratificação federativa e, com isso se possa definir com exatidão a quem compete cumprir qual tarefa prestacional. Do contrário, corre-se o risco de ineficácia dos textos que, pura e simplesmente, se referem genericamente à palavra "Estado" - sem melhor desenvolvê-la em seu conteúdo semântico e técnico-jurídico.

A Constituição de 1988, ao prever a convivência independente, mas harmoniosa entre os poderes constituídos, institui de forma clara e expressa a noção de cooperação entre poderes. De igual sorte, portanto, deve se dar a convivência entre as unidades da federação: União, estados, municípios e o Distrito Federal.

Faz-se necessário rever o arranjo federativo, para redefinição da densidade distributiva de competências e, sobretudo, de fontes de recursos que financiem as correspondentes iniciativas, em termos de políticas públicas e de açóes a realizar, entre os atores de políticas, no sentido de descentralizar atribuiçóes e recursos para mais próximo de seus destinatários; da mesma ratio será a necessária expansão dos instrumentos de controle de accontability, afinal, quanto mais ampla a autonomia decisória, maior a responsividade, quanto aos resultados, e a responsabilidade, quanto aos repasses e dispêndios de recursos públicos ou de terceiros.

Os princípios fundamentais da República Federativa do Brasil instam de igual forma a força cooperativa, ao pugnar pela redução das desigualdades regionais e sociais; pela supressão da marginalização e da miséria e, sobretudo, pela construção de uma sociedade mais livre, justa e "solidária" (art. 30) ${ }^{71}$.

Se para fins interpretativos o alcance da palavra "solidária" não for suficiente a instigar a operação conjunta (cooperação) entre os entes federativos, recorra-se, então, à

71 "Art. 3 Constituem objetivos fundamentais da República Federativa do Brasil: I - construir uma sociedade livre, justa e solidária; II - garantir o desenvolvimento nacional; III - erradicar a pobreza e a marginalização e reduzir as desigualdades sociais e regionais; IV - promover o bem de todos, sem preconceitos de origem, raça, sexo, cor, idade e quaisquer outras formas de discriminação." 
compreensão da expressa literalidade do art. $23^{72}$, parágrafo único, que póe claramente a "cooperaçáo" como dever político, jurídico e social, a predizer que: "Leis complementares fixarão normas para a cooperação entre a União e os Estados, o Distrito Federal e os Municípios, tendo em vista o equilíbrio do desenvolvimento e do bem-estar em âmbito nacional".

Os problemas com a efetivação de direitos sociais ultrapassam as fronteiras da compreensão da deficiência estrutural específica para encontrar como fonte, invariavelmente, a baixa capacidade de compreensão, as restriçôes de acesso à educação que findam por prejudicar a capacidade de planejamento de cada família, conduzindo a escolhas por vezes equivocadas o que finda por acentuar o problema que se procura resolver, como exemplificamos com a questão das migraçôes concentradoras de população nos grandes centros urbanos.

As constantes demandas por prestaçóes sociais reclamam invariavelmente por recursos do poder público a fim de se ver atendidas as necessidades mais prementes da sociedade, isso também conduz com certa frequência ao conflito de interesses entre unidades componentes de federação, seja quanto ao desenho de regras restritivas que lhes alcancem, seja na repartição de receitas oriundas de arrecadação conjunta pelo poder central, contribuindo para o estabelecimento de um equilíbrio que oscila entre a estabilidade política e a tensão financeira.

Sob a ótica investigativa, em termos de políticas habitacionais, a história brasileira demonstra que há reduzida capacidade de inverter o jogo deficitário habitacional e, a cada dia, aumenta a pressão social por moradia. As políticas públicas habitacionais seguiram o centralismo concentrado pela Uniâo, sem maior destaque para açóes regionais que pudessem, no todo, contribuir para um resultado geral de benefício habitacional.

$\mathrm{O}$ Estado, portanto, náo se mostrou capaz de garantir nem uma igualdade material habitacional, e nem mesmo, a parcela mínima de dignidade existencial, em termos de direito social à moradia, se viu atendida, fosse por meio de suas intervençóes operativas, fosse por meio de reformas estruturais. A proporção que o problema apresenta é crescente, confirmado pelo aumento crescente de pessoas vivendo em habitaçôes com condiçôes de sub-humanidade - tais como as favelas e assemelhados, que vivem explosão demográfica, fruto das intensas migraçóes para os grandes centros urbanos.

Os interesses da população, em especial, a de baixa renda, são sistematicamente atendidos de modo muito parcial e incompleto, por vezes, injusto, disponibilizando prestações

72 “Art. 23. Parágrafo único. Leis complementares fixarão normas para a cooperação entre a Uniāo e os Estados, o Distrito Federal e os Municípios, tendo em vista o equilíbrio do desenvolvimento e do bem-estar em âmbito nacional." 
que se concentram nas mãos da classe média e, por vezes, até beneficiaram a classe mais alta, sem, contudo, atentar eficazmente para o problema das classes mais modestas.

Essas, portanto, as equaçóes que, repletas de variáveis se apresentam à espera de soluçóes pelo Estado brasileiro em termos de políticas públicas, prestações sociais, e, sobretudo, obtenção, da melhor repartição e da consequente alocação de recursos financeiros capazes de atendê-las. Tais demandas se mostram cada vez mais distantes quanto ao atendimento, em especial, no contexto recessivo que ora se instaura, decorrente da crise política e de moralidade, com consequente queda da confiabilidade do Brasil como destinatário de investimentos externos, conduzindo ao encolhimento da oferta de crédito em todas as áreas, inclusive a imobiliária, e levando à explosão das taxas de juros. Cada vez mais distante restou o sonho da casa própria para milhóes de brasileiros.

\section{Referências}

BOTEGA, Leonardo da Rocha. A Política Habitacional no Brasil (1930-1990). Revela -Revista Eletrônica Acadêmica da FALS, ano I, n. 2, pp. 1-14, mar. 2008.

BUENO, Laura Machado Mello. Projeto e favela: metodologia de projeto de urbanização de favelas. 2000. 176 p. Tese (Doutorado em Arquitetura e Urbanismo) - Universidade de São Paulo, São Paulo.

CAMPOS, Núbia Carla. A efetividade do direito à moradia no judiciário brasileiro: uma análise comparativa da jurisprudência. 2011. Monografia apresentada para conclusão da Escola de Formação da SBDP. Disponível em: <http://www.sbdp.org.br/monografias_ver. php?idConteudo=175>. Acesso em 21 fev. 2013.

CANOTILHO, José Joaquim Gomes. A Constituição Dirigente e a Vinculação do Legislador - contributo para a compreensão das normas constitucionais programáticas. Coimbra: Almedina, 2001.

DIAS, Reinaldo et MATOS, Fernanda. Politicas Públicas-princípios, propósitos e processos. São Paulo: Atlas, 2012.

MEDEIROS, Sara Raquel Fernandes Queiroz de. BNH: outras perspectivas. Disponível em: <http://www.cchla.ufrn.br>. Acesso em 27 fev. 2013.

MILAGRES, Marcelo de Oliveira. Direito à moradia. São Paulo: Atlas, 2011, 225 p.

MOTTA, Luana Dias. A questão da habitação no Brasil: políticas públicas, conflitos urbanos e o direito à cidade. 2011. Acesso em 16 fev. 2013. Disponível em: <http://conflitosambientaismg.lcc.ufmg.br>.

NOGUEIRA, Joilma Sampaio. Políticas públicas de habitação no Brasil: uma análise do Programa de Urbanização e Regularização de Assentamentos Precários no Município de Santo Antônio de Jesus - BA. Faculdade Adventista da Bahia, Cachoeira, 2010. 
RANGEL, Helano Márcio Vieira et SILVA, Jacilene Vieira da. O direito fundamental à moradia como mínimo existencial, e a sua efetivação à luz do Estatuto da Cidade. Veredas do Direito, Belo Horizonte, v. 6, p. 57 - 78, jul.-dez. 2009.

SARLET, Ingo Wolfgang (Org.). Direitos Fundamentais Sociais: estudos de Direito Constitucional, Internacional e Comparado. Rio de Janeiro: Renovar, 2003.

SARLET, Ingo Wolfgang. A Eficácia dos Direitos Fundamentais. 10 ed. rev. ampl. atual. Porto Alegre: Livraria do Advogado, 2010.

SARLET, Ingo Wolfgang. Notas a respeito do direito fundamental à moradia na jurisprudência do Supremo Tribunal Federal. In: SARMENTO, Daniel; SARLET, Ingo Wolfgang (Coord.). Direitos fundamentais no Supremo Tribunal Federal: balanço e crítica. Rio de Janeiro: Lumen Juris, 2011. pp. 687-721. 